\title{
RAGAM BAMBU DAN KAYU KENTONGAN: SEBUAH KAJIAN ETNOBOTANI DI JAWA, BALI, DAN LOMBOK
}

\author{
Various Bamboo and Wood "Kentongan": An Etnobotany Study in Java, Bali and Lombok
}

\author{
Emma Sri Kuncari*, Marwan Setiawan \\ Pusat Penelitian Biologi, Lembaga Ilmu Pengetahuan Indonesia (LIPI) \\ Cibinong Science Center, Jl. Raya Jakarta Bogor KM. 46, Cibinong, Bogor, Jawa Barat
}

\section{Informasi Artikel}

Diterima/Received : 24 Mei 2021

Disetujui/Accepted : 28 Agustus 2021

Diterbitkan/Published : 31 Agustus 2021

*Koresponden E-mail :

emmakuncari@gmail.com

DOI: https://doi.org/10.14203/bkr.v24i2.731

\section{Cara mengutip}

Kuncari ES, Setiawan M. 2021. Ragam bambu dan kayu kentongan: Sebuah kajian etnobotani di Jawa, Bali, dan Lombok.

Buletin Kebun Raya 24(2): 85-92.

DOI: https://doi.org/10.14203/bkr.v24i2.731

\section{Kontributor}

\section{Kontributor Utama/Main author:}

Emma Sri Kuncari

Kontributor Anggota/Author member: Marwan Setiawan

Keywords: bamboo, ethnobotany, kentongan, wood

Kata Kunci: bambu, etnobotani, kayu, kentongan

\begin{abstract}
Kentongan is known as a traditional communication tool which is made from bamboo and wood. Even though information and technology rapidly developed nowadays, kentongan is still well-known and used by some Indonesian people. An ethnobotanical study was conducted to examine local wisdom of the community regarding kentongan more deeply. Randomly selected interviewer method is used to observe several areas in Indonesia. The data were analyzed by descriptive qualitative. The results found that various bamboo and wood are used namely, ori bamboo (Bambusa blumeana Schult.f.), petung bamboo (Dendrocalamus asper (Schult.) Backer), apus bamboo (Gigantochloa apus (Schult.) Kurz)), wulung bamboo (G. atroviolacea Widjaja), jackfruit wood (Artocarpus heterophyllus Lam.), teak wood (Tectona grandis L.f.), coconut wood (Cocos nucifera L.), mahagoni wood (Swietenia mahagoni (L.) Jacq.), and sengon wood (Albizia chinensis (Osbeck) Merr.). The Kentongan vary in size as well as in shape. Social and religious values of kentongan are in line with current development as well as conservation of its raw material and also can preserve cultural value. Therefore, kentongan is still needed for sustainability and regulation in living together among communities.
\end{abstract}

\begin{abstract}
Abstrak
Kentongan dikenal sebagai salah satu alat komunikasi tradisional yang memanfaatkan bambu dan kayu. Sebagian masyarakat Indonesia masih mengenal dan menggunakan kentongan di tengah pesatnya perkembangan teknologi dan informasi seperti saat ini. Studi etnobotani dilakukan untuk mengkaji lebih mendalam tentang kearifan lokal masyarakat mengenai kentongan. Metode yang digunakan berupa observasi di beberapa wilayah di Indonesia dan wawancara secara acak terpilih. Data yang dikumpulkan dianalisis secara deskriptif kualitatif. Hasil kajian diperoleh data keanekaragaman jenis bambu dan kayu kentongan yaitu bambu ori (Bambusa blumeana Schult.f.), bambu petung (Dendrocalamus asper (Schult.) Backer), bambu apus (Gigantochloa apus (Schult.) Kurz), bambu wulung (G. atroviolacea Widjaja), kayu nangka (Artocarpus heterophyllus Lam.), kayu jati (Tectona grandis L.f.), kayu kelapa (Cocos nucifera L.), kayu mahoni (Swietenia mahagoni (L.) Jacq.), dan kayu sengon (Albizia chinensis (Osbeck) Merr.). Ukuran dan bentuk fisik kentongan bervariasi. Nilai-nilai sosial dan religius kentongan sejalan dengan perkembangan zaman, serta penyelamatan nilai budaya dan konservasi keanekaragaman hayati bahan baku kentongan agar tidak terkikis perubahan zaman. Dengan demikian, masyarakat masih menggunakan kentongan secara lestari untuk mengatur pola hidup kebersamaan dalam masyarakat.
\end{abstract}

\section{PENDAHULUAN}

Kentongan masih dikenal oleh sebagian masyarakat Indonesia sampai saat ini. Beberapa tempat masih menggantung kentongan dengan alat pemukulnya, namun kurang jelas maknanya apakah hanya sekedar hiasan ataukah masih digunakan untuk komunikasi warga. Bakker (1992) sangat setuju mensosialisasikan kentongan karena nilai seni dan keindahannya untuk mewujudkan nilai rasa dan mewakili kebudayaan dalam arti luas. Kamus Besar
Bahasa Indonesia (KBBI) mengartikan kentongan (kentungkentung) sebagai bunyi-bunyian yang berasal dari bambu atau kayu berongga, dipukul untuk menyatakan tanda waktu, bahaya atau mengumpulkan massa. Asal mula nama kentongan dikarenakan bunyinya "thung...thung" (Jawa). Buku Ensiklopedi Umum menyebutkan kentongan terbuat dari kayu atau bambu dengan panjang yang berbeda-beda, di tengahnya terdapat alur/rongga memanjang, yang bila dipukul dengan tongkat pemukulnya maka udara di dalamnya akan beresonansi sehingga 
memperkuat suara (Sumiyati 2007). Menurut Surono (2015), kentongan memiliki nilai 'sesuatu' yang perlu dipertahankan dan mampu bertahan dan bersaing dengan alat komunikasi modern, meskipun kentongan digolongkan sebagai alat komunikasi tradisional, sebagaimana halnya dengan asap dan burung merpati. Kelebihan lainnya yaitu sebagai sarana menjaga pola hidup kebersamaan yang jauh dari sikap egoisme, mampu menjadikan masyarakat saling menghargai, dan peduli satu dengan lainnya

Kajian mengenai kentongan telah dilakukan oleh para peneliti dan akademisi di Indonesia. Menurut Yunus et al. (1994), kentongan merupakan sebuah perangkat komunikasi tradisional yang tidak memiliki unsur teknologi modern. Fenomena bunyi kentongan juga menarik Sugiyarti (2012) untuk melakukan penelitian tentang perbedaan frekuensi kentongan yang dilakukan dengan teknik pemukulan yang berbeda. Namun demikian, informasi yang memadai mengenai keanekaragaman bahan baku (tumbuhan) yang lazim dipergunakan dalam pembuatan kentongan belum pernah dilaporkan. Oleh karena itu, penelitian ini bertujuan untuk mengungkapkan keanekaragaman jenis bambu dan kayu, nilai-nilai sosial dan religius, dan upaya konservasi nilai budaya dan keanekaragaman hayati bahan baku pembuat kentongan.

\section{METODE}

\section{Lokasi dan waktu penelitian}

Penelitian ini dilakukan melalui observasi (pengamatan langsung) di beberapa wilayah di Jawa, Bali, dan Lombok yang masih dijumpai dan memanfaatkan kentongan dalam kehidupan sehari-hari (Gambar 1). Adapun lokasi penelitian tersebut adalah sebagai berikut: Lokasi A (Jawa) dilakukan di Yogyakarta (Wirobrajan, Cangkringan, dan Maguwoharjo), Jawa Tengah (Klaten: Bayat, Gantiwarno, dan Wedi), Jawa Timur (Ngawi dan Madura); Lokasi B (Bali) dilakukan di Denpasar; dan Lokasi C (Lombok) dilakukan di Mataram. Adanya keterbatasan sumber daya, maka observasi di daerah Jawa Barat yang juga memiliki tradisi kentongan cukup menonjol belum dapat dilakukan. Penelitian ini dilaksanakan selama tiga bulan, yaitu pada bulan Oktober-Desember 2020.

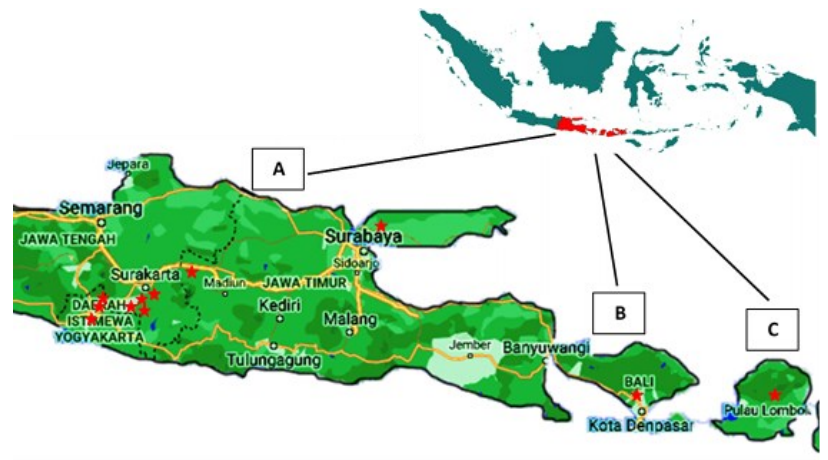

Pengamatan spesimen herbarium dari bambu dan kayu dilakukan di Herbarium Bogoriense, Bidang Botani, Pusat Penelitian Biologi-LIPI. Pengamatan koleksi artefak kentongan dilakukan di Museum Nasional Sejarah Alam Indonesia (Munasain), Bogor.

\section{Bahan, alat dan analisis data}

Wawancara dilakukan terhadap 40 orang informan dengan memberikan pertanyaan seputar kentongan yang meliputi konsep, jenis, bahan, pemanfaatan, cara pembuatan, nilai-nilai sosial, dan religius hingga konservasinya. Di setiap lokasi terpilih (tanpa membedakan tingkat provinsi ataupun desa), maka dipilih dua orang informan (total 20 orang informan dari 10 lokasi) yang merupakan informan kunci (tokoh adat/sesepuh kampung atau praktisi/pembuat kentongan yang paham, sudah lama dan intensif berhubungan dengan kentongan, serta memiliki cukup waktu dan kesempatan untuk dimintai keterangan). Dipilih juga secara acak dua orang responden (total 20 orang informan dari 10 lokasi) non informan kunci (orang-orang yang hanya menggunakan kentongan dalam kehidupan sehari-hari), dari beberapa wilayah di Jawa, Bali, dan Lombok. Untuk melengkapi data lapangan yang kurang memadai, maka dilakukan penelusuran pustaka. Data yang terkumpul dianalisis secara deskriptif kualitatif. Pada penelitian ini digunakan pendekatan emik dengan tujuan memperoleh data mengenai pengetahuan masyarakat tentang objek yang sedang diamati menurut kacamata dan bahasa mereka, dilanjutkan dengan pendekatan etik yaitu pendekatan berdasarkan sudut pandang ilmu pengetahuan (Martin 1995; Walujo 2004)

\section{HASIL DAN PEMBAHASAN}

\section{Keanekaragaman jenis bambu dan kayu}

Penelitian pada beberapa lokasi di Jawa dan Bali mengungkapkan bahwa tidak semua bambu dapat dijadikan kentongan. Beberapa pertimbangan khusus diperlukan dalam memilih bahan baku pembuatan kentongan, antara lain keawetan dan suara yang dihasilkan. Bagian bambu yang biasanya digunakan dalam membuat kentongan adalah bagian batang atau bongkol.

Kentongan yang terbuat dari bongkol bambu akan menghasilkan suara yang lebih nyaring, dapat dibuat dalam beragam bentuk, dan lebih awet dibandingkan dengan kentongan yang terbuat dari batang bambu. Bagian bongkol ini biasanya lebih tebal dan keras sehingga dapat dibentuk sesuai dengan yang diinginkan oleh pembuatnya. Menurut Surono (2015), kentongan yang terbuat dari bongkol bambu ini memiliki tingkat kesulitan yang jauh lebih tinggi, sehingga harganya jauh lebih mahal

Gambar 1. Lokasi penelitian (sumber: Google map) 
dibandingkan dengan kentongan yang terbuat dari batang bambu.

Kentongan yang terbuat dari bambu ini dalam Bahasa Jawa disebut 'thethekan'. Jika pada pos ronda di Jawa biasa menggunakan kentongan yang terbuat dari bambu, maka masyarakat di Bali biasanya membuat kentongan yang dibuat dari batang kayu. Kentongan kayu dapat dibuat dalam beragam bentuk seperti bentuk ikan, tubuh orang, dan kepala raksasa (Sumiyati 2007).

Beberapa jenis bambu dan kayu yang dijadikan pilihan dalam membuat kentongan adalah sebagai berikut:

1. Bambu ori (Bambusa blumeana Schult.f.).
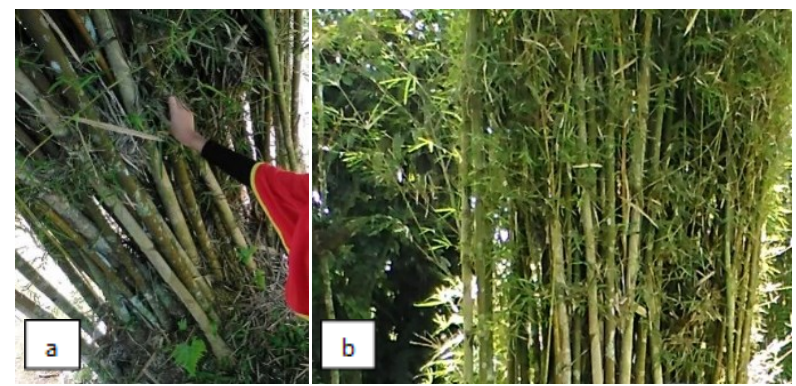

Gambar 2. Bambu ori (dokumentasi pribadi)

Ciri-ciri bambu ori yaitu rebungnya dengan miang hitam, sering kali dengan garis kuning pada pelepahnya. Batang muda berlilin putih sehingga tampak abu-abu, dengan cabang yang penuh duri sehingga tampak rumpun sangat padat (Gambar 2). Percabangan tumbuh di atas tanah dengan cabang utama lebih besar daripada cabang sampingnya (Widjaja \& Karsono 2005). Tekstur batang padat dan tebal, berdaun kecil-kecil, ranting banyak dan berduri. Biasanya bambu ini dijadikan bahan konstruksi karena kekuatan batangnya (Muryanto 2020), sedangkan untuk membuat kentongan bagian yang digunakan adalah bongkolnya (Surono 2015).

2. Bambu petung (Dendrocalamus asper (Schult.) Backer) Jenis ini memiliki rebung kehitaman dengan miang cokelat kehitaman menutupi seluruh rebungnya. Pangkal batang muda ditutupi oleh bulu cokelat membeludru, sedangkan batang bagian atas ditutupi lilin putih sehingga warna batang menjadi hijau keputihan, dan akan menghilang Ketika batang menua. Percabangan muncul pada bagian tengah hingga atas buluhnya (Gambar 3) (Widjaja \& Karsono 2005). Tekstur batangnya padat seperti halnya bambu ori dan relatif lebih pendek, namun terdapat bulu pada ruasnya. Rebungnya sering dijadikan sebagai bahan masakan karena tekstur yang lebih empuk (Muryanto 2020). Bongkol bambu petung digunakan untuk membuat kentongan karena memiliki bentuk unik dan kuat (Surono 2015).

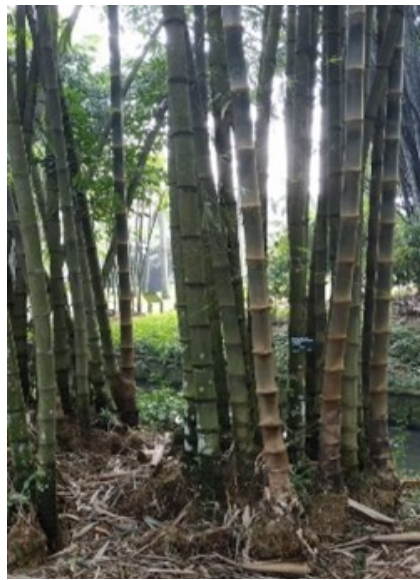

Gambar 3. Bambu petung (dokumentasi pribadi)

3. Bambu apus (Gigantochloa apus (Schult.) Kurz).

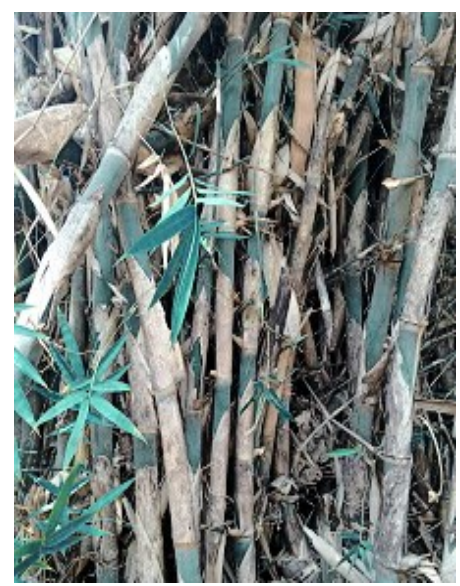

Gambar 4. Bambu apus (dokumentasi pribadi)

Bambu apus berasal dari Myanmar dan Thailand bagian tenggara kemudian masuk ke Jawa oleh adanya migrasi (Dransfield \& Widjaja 1995). Jenis ini umumnya tumbuh di dataran rendah meskipun dapat tumbuh dengan baik di daerah pegunungan sampai dengan ketinggian $1000 \mathrm{~m}$ dpl. (Supriatna \& Kosasih 2014). Tekstur batangnya lebih tipis, daun lebar, dan terdapat bulu pada ruasnya (Gambar 4). Batangnya dimanfaatkan sebagai bahan kerajinan tangan, seperti besek, tampah, dan tumbu (tempat beras/nasi) (Muryanto 2020), sedangkan rebungnya dapat digunakan untuk membantu mengobati rematik, panas dalam, dan demam (Sujarwo et al. 2010). Jenis ini hanya bisa dimanfaatkan batangnya saja, sedangkan bongkolnya tidak dapat digunakan untuk membuat kentongan (Surono 2015). 
4. Bambu wulung/hitam/gombong (Gigantochloa atroviolacea Widjaja)

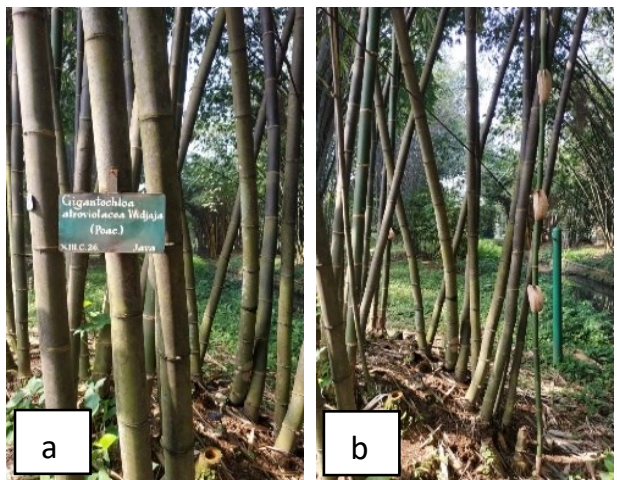

Gambar 5. Bambu wulung (dokumentasi pribadi)

Jenis bambu wulung/hitam/gombong dapat dilihat dari bentuk batangnya yang berwarna hitam, tekstur lebih tipis, ruas lebih panjang, tinggi, dan lurus dengan jumlah ranting sedikit (Gambar 5). Jenis ini biasa digunakan sebagai bahan interior dan bahan bangunan/konstruksi. Menurut Muryanto (2020), jenis bambu ini sudah mulai jarang ditemui, hanya terdapat di Jawa, tumbuh baik dan subur di daerah yang memiliki tanah kering dan berkapur, serta dapat tumbuh di tanah vulkanik yang berwarna kemerahan (Widjaja 2001). Bagian yang dimanfaatkan untuk membuat kentongan adalah batangnya (Surono 2015).

5. Kayu nangka/ketewel (Artocarpus heterophyllus Lam.)

Kayu pohon nangka, terutama yang sudah "nggalih" (tua) adalah salah satu jenis kayu yang banyak dipilih untuk membuat kentongan (Gambar 6). Pohon nangka berasal dari India dan kemudian menyebar sampai ke Indonesia. Nangka di Indonesia saat ini sudah mencapai sekitar 30 kultivar (Hettiaratchi et al. 2011). Pohon nangka tergolong pohon berukuran sedang, tinggi 8-25 m, diameter batang $30-80 \mathrm{~cm}$, percabangan dekat dengan pangkalnya; ranting terkadang ditutupi oleh bulu-bulu halus; daun sederhana, berseling, ukuran helaian daun 9-23 × 5-12 $\mathrm{cm}$, membulat telur sungsang dengan pinggiran rata; pohon nangka biasanya mengeluarkan getah berwarna putih (Komor \& Devi 2016; Wit \& Luke 2017),

Kayu pohon nangka banyak dipilih untuk bahan baku pembuatan kentongan karena serat kayunya lebih padat (Sadguna 2010) dan kualitas suara yang dihasilkan lebih bagus, sehingga tidak membuat orang yang memukulnya "kebrebegan" (bising) serta jangkauan suaranya jauh (Surono 2015). Selain itu, kayu nangka juga telah lama dikenal dan digunakan dalam berbagai keperluan mulai dari pembuatan mebel, konstruksi bangunan, pembubutan, tiang kapal, tiang kuda, kandang sapi, dayung, perkakas, sampai alat musik (Prihatman 2000).

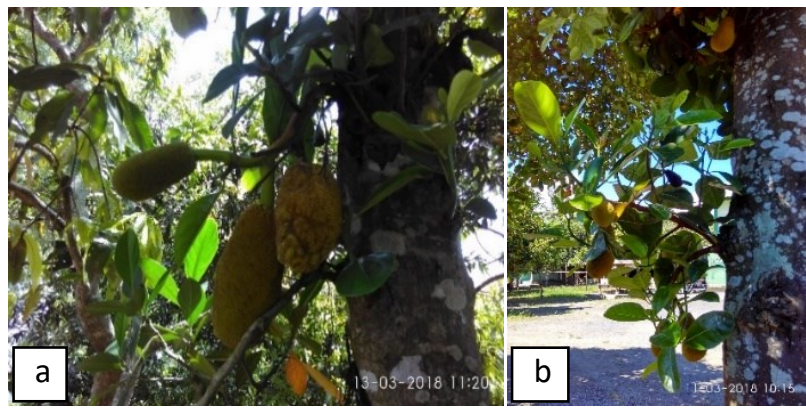

Gambar 6. Pohon nangka (dokumentasi pribadi)

6. Kayu jati/teges (Tectona grandis L.f.)

Jati merupakan jenis asli dari Myanmar, yang kemudian menyebar ke Semenanjung India, Thailand, Filipina, dan Jawa. Karakter secara umum berupa pohon besar dengan batang yang bulat lurus, tinggi mencapai $40 \mathrm{~m}$, kulit batang cokelat kuning keabuabuan, daun berbentuk elips yang lebar, dan dapat mencapai 30-60 cm saat dewasa (Akram \& Aftab 2007). Pohon jati beradaptasi dengan baik pada kondisi lingkungan yang mempunyai musim kering nyata, curah hujan 1200-3000 mm/tahun, intensitas cahaya 75$100 \%$, suhu $22-31{ }^{\circ} \mathrm{C}$, dan ketinggian tempat $0-700 \mathrm{~m}$ dpl. (Gambar 7) (Pudjiono 2014). Pohon jati dikenal sebagai patihnya kayu, seperti disebutkan dalam naskah Janantaka: "kita taru jati, wenang kita mematuhi, patih jati pangaranata, wenang patih pangwesanta ring sahaning taru iki kabeh. Mwang kita comel pengaranta, amisesa ikang taru rencek" (Kau kayu jati, patut menjadi patih, patih jati namamu, patut sama kedudukanmu pada kayu nangka, menguasai kayu semua) (Anonim 2020b).
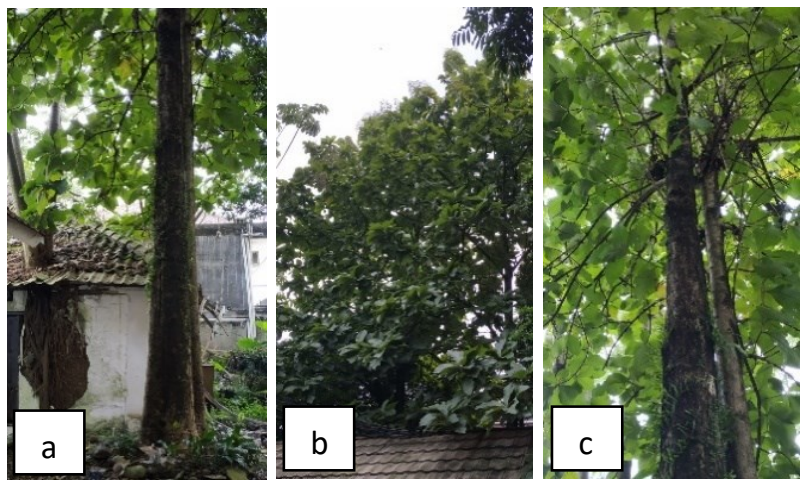

Gambar 7. Pohon jati (dokumentasi pribadi)

7. Kayu kelapa (Cocos nucifera L.)

Kelapa merupakan salah satu tanaman yang memiliki nilai guna yang tinggi dalam kehidupan masyarakat. Jenis ini diperkirakan berasal dari pesisir Samudera Hindia di sisi Asia, dan kini menyebar luas ke seluruh pantai dunia (Gambar 8) (Winarno 2014). Pohon ini memiliki batang tunggal, akar serabut, tebal, dan berkayu, berkelompok membentuk bonggol, dan adaptif pada lahan berpasir pantai. Batangnya beruasruas, namun bila sudah tua tidak terlalu tampak, khas tipe monokotil dengan pembuluh menyebar (tidak 
konsentrik), berkayu, daun majemuk dengan pertulangan menyirip; buah besar, diameter $10-20 \mathrm{~cm}$ atau lebih, berwarna kuning, hijau, atau cokelat (Anonim 2014).

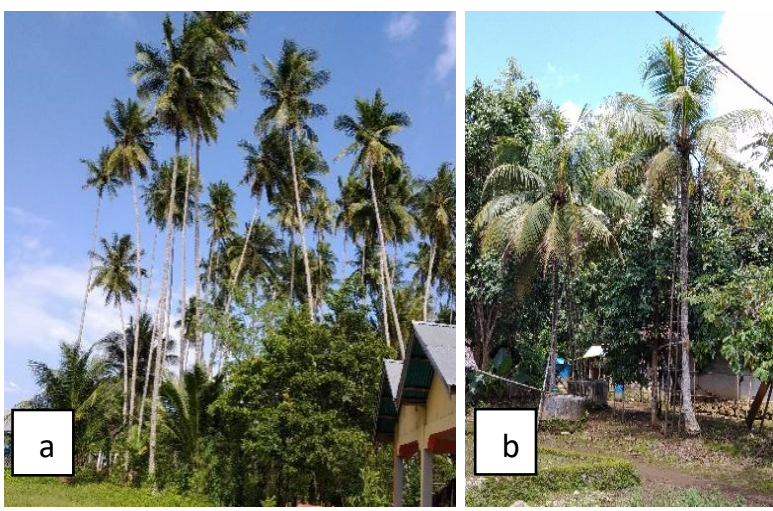

Gambar 8. Pohon kelapa (dokumentasi pribadi)

8. Kayu mahoni (Swietenia mahagoni (L.) Jacq.)

Pohon mahoni berasal dari Hindia Barat, kemudian tersebar luas hingga Srilanka, India, Indonesia, Sarawak, dan Fiji. Jenis tanaman ini mulai masuk ke Indonesia pada tahun 1872 melalui India. tanaman ini berkembang pesat di Jawa sekitar tahun 1892-1902 dan semakin banyak dibudidayakan oleh masyarakat Indonesia sampai sekarang (Larasati 2018). Mahoni merupakan pohon dengan tinggi 10-20 m dan berdiameter lebih dari $100 \mathrm{~cm}$ (Gambar 9). Sistem perakarannya berupa akar tunggang; batang bulat, cokelat tua keabu-abuan dan memiliki banyak cabang sehingga kanopi berbentuk payung dan sangat rimbun (Suhono 2010). Pada umumnya, kentongan di Bali terbuat dari batang pohon mahoni yang dibentuk seperti ikan, sehingga dinamakan "kulkul" (Sumiyati 2007).

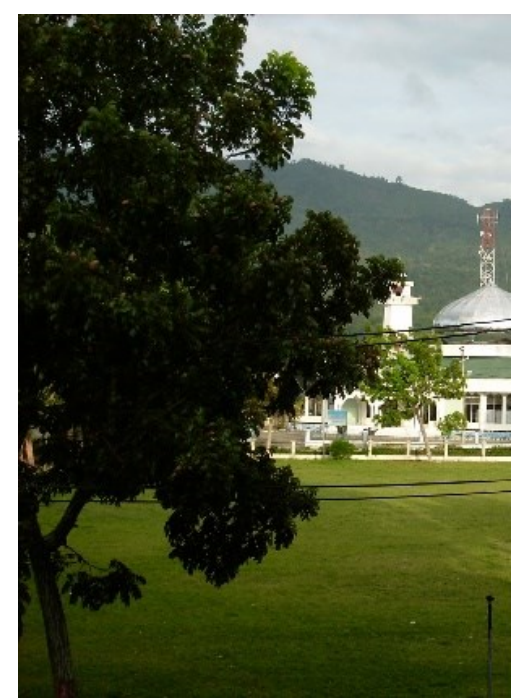

Gambar 9. Pohon mahoni (dokumentasi pribadi)

9. Kayu sengon (Albizia chinensis (Osbeck) Merr.)

Sebaran alami sengon meliputi India, Myanmar, Thailand, Kamboja, Laos, Cina, Vietnam, dan Indonesia, kemudian di introduksikan ke Australia. Di Indonesia, sengon menyebar di Jawa, Bali, dan Nusa Tenggara, selanjutnya disebarkan dan dibudidayakan di Sumatra dan Kalimantan (Orwa et al. 2009). Pohon sengon memiliki kayu yang berwarna hampir putih atau cokelat muda, tekstur agak kasar, dan merata serta arah serat lurus, bergelombang lebar atau berpadu (Gambar 10) (Pandit \& Kurniawan 2008).

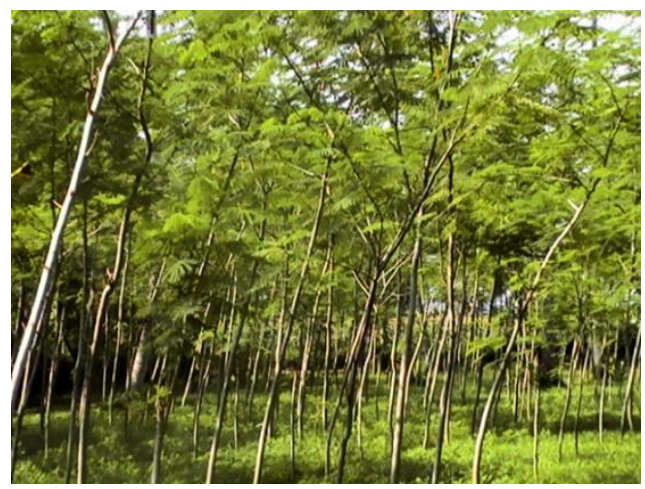

Gambar 10. Pohon sengon (dokumentasi pribadi)

Masyarakat di Jawa percaya bahwa ada beberapa bahan untuk membuat kentongan, salah satunya adalah kayu sengon. Semakin bagus kualitas kayunya, tentu semakin berkualitas bunyi yang dihasilkan. Menurut Suarna (2020), pemilihan kayu untuk kentongan sedapat mungkin yang berbatang lurus dan bebas dari bekas cabang karena akan mempengaruhi resonansi suara. Kayu yang sudah dipotong sesuai ukuran, kemudian dikeringkan anginkan secara alami (tidak boleh dijemur). Keadaan ini harus dipertahankan minimal selama lima tahun, agar kadar airnya hilang dan pori-pori seratnya menjadi sangat rapat.

\section{Ukuran dan bentuk fisik kentongan}

Berdasarkan hasil wawancara, kentongan secara fisik tidak memiliki ukuran dan bentuk baku, umumnya sangat bergantung pada selera masyarakat berdasarkan fungsi dan kepemilikannya. Masyarakat di Jawa, Bali, dan Lombok biasanya memiliki kentongan pribadi yang panjangnya 40-70 cm, sedangkan kentongan untuk umum maupun peribadatan biasanya berukuran lebih besar dengan panjang dapat mencapai lebih dari $1 \mathrm{~m}$ (Gambar 11), bahkan menurut Yunus (1994) dapat mencapai $2 \mathrm{~m}$.

Bentuk fisik kentongan di Jawa, Bali, dan Lombok terbagi menjadi dua macam, yaitu polos dan berukir. Kentongan dengan bentuk polos banyak digunakan pada fasilitas umum, terutama di Jawa, sedangkan di Bali lebih menggunakan kentongan berukir (hias) untuk menarik wisatawan, sekaligus mendukung sarana pariwisata (Yunus 1994). 

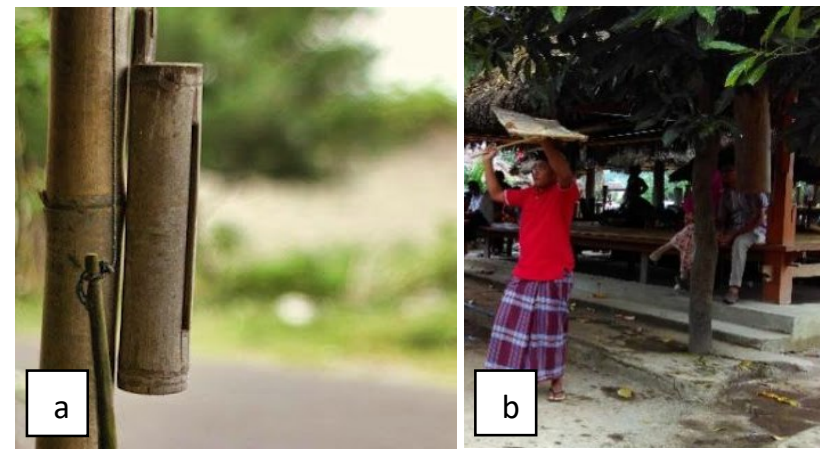

Gambar 11. Jenis kentongan. a. Kentongan bambu; b. kentongan kayu (dokumentasi pribadi)

\section{Nilai-nilai sosial dan religius}

Kentongan merupakan salah satu contoh alat komunikasi tradisional yang berkaitan dengan nilai sosial maupun religius (keagamaan). Menurut Paramudita (2014), kentongan merupakan salah satu sarana penyampaian informasi non-verbal bagi masyarakat. Penggunaan kentongan dalam keperluan sosial dapat dengan mudah dikenali dari nada dan tempo yang dibunyikan. Ketukan dengan tempo perlahan menandakan bahwa kondisi aman, misalnya kentongan yang dibunyikan oleh para petugas jaga di pos-pos ronda. Nada dengan tempo cepat ('gobyok/titir') tanpa jeda merupakan pertanda adanya bahaya yang datang, misalnya bencana alam seperti banjir, angin topan, kebakaran, tanah longsor, dan kedatangan hewan buas (Anonim 2020a). Nilai-nilai sosial dan religius kentongan antara lain:

1. Nilai Sosial

kentongan berfungsi sebagai sarana informasi peristiwa tertentu, undangan, hiasan, alat musik, dan pembukaan suatu acara, khususnya di Yogyakarta dan Jawa Tengah. Kentongan sebagai sarana informasi biasa dibunyikan pada saat ada peristiwa tertentu di lingkungan mereka yang berkaitan dengan kondisi aman dan tidak aman, misalnya ketika ada kematian, pencurian, kebakaran, dan banjir, masing-masing menggunakan irama pukulan yang berbeda. Menurut Sumiyati (2007), kearifan lokal masyarakat di sekitar Sungai Krasak (lereng Gunung Merapi) dikenal dengan nama "lampor" yaitu informasi peringatan dini dengan memukul kentongan bila dusun yang berada paling atas mengalami kebanjiran.

Nilai sosial lainnya adalah sebagai sarana mengundang seseorang atau masyarakat untuk mendatangi tempat dan kegiatan tertentu, misalnya gotong-royong, "kenduren" untuk memperingati harihari besar, rapat kampung, dan posyandu. Masyarakat Bali umumnya menggantung dua "kulkul" pada bale "kulkul" yang mencerminkan laki-laki dan perempuan. Apabila suatu kegiatan hanya akan mengundang peserta perempuan, maka yang dibunyikan "kulkul" beridentitas perempuan, begitu sebaliknya dan kalau mengundang laki-laki dan perempuan, maka kedua "kulkul" harus dibunyikan (Anonim 2020b).

2. Nilai Religius

Berdasarkan hasil pengamatan di lapangan, saat ini kentongan masih menghiasi beberapa tempat ibadah, khususnya masjid pada masyarakat Jawa dan pura pada masyarakat Bali. Kentongan biasanya juga dilengkapi dengan "bedhug", yang umumnya diletakkan berdekatan, karena pada saat tertentu keduanya akan dibunyikan bergantian sebagai penanda waktu sholat (Gambar 12). Di Bali, "kulkul” digantung pada pohon kamboja di dekat atau halaman kuil. "Kulkul sekaha" dipukul untuk mengumpulkan massa pada suatu kegiatan bersama, misalnya berkaitan subak atau upacara keagamaan (Sumiyati 2007).

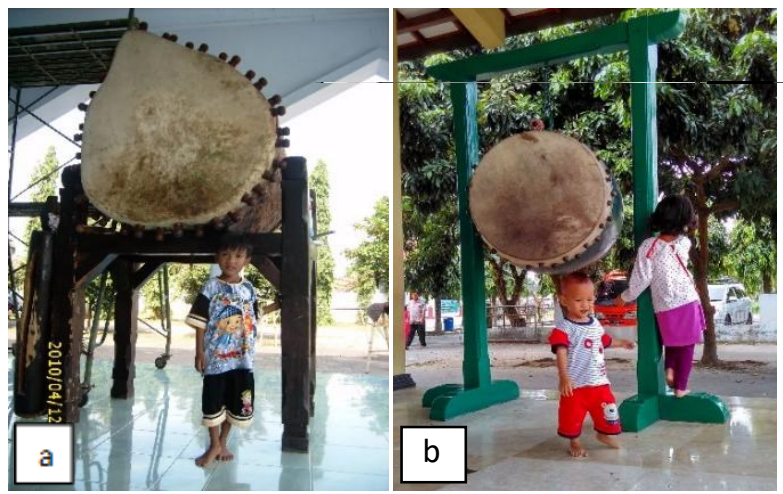

Gambar 12. Kentongan kayu dan "bedhug" (dokumentasi pribadi).

\section{Penyelamatan nilai budaya dan konservasi keanekaragaman hayati bahan baku}

Dalam batasan dan cakupan konservasi, paling tidak terdapat empat nilai yang terkandung dalam konsep konservasi, yaitu menanam, memanfaatkan, melestarikan dan mempelajari (Rachman 2012). Penelitian ini mengungkap upaya konservasi nilai budaya dan konservasi keanekaragaman bahan baku untuk membuat kentongan sebagai berikut:

1. Penyelamatan nilai budaya

Berdasarkan hasil wawancara dengan informan kunci dan informan non kunci, masyarakat telah memberi makna-makna tertentu pada kentongan yang cukup kuat melekat dalam kehidupan sehari-hari, misalnya untuk menggambarkan identitas, status sosial, dan keharmonisan sosial. Masyarakat sadar dan terus berupaya mengambil manfaat dan melestarikan nilai-nilai budaya yang berkaitan dengan kentongan, terutama nilai-nilai yang sifatnya baik. Kentongan sebagai identitas kebudayaan digunakan untuk menunjukkan bahwa masyarakat hidup dalam kebersamaan dan diperlakukan sejajar dengan anggota masyarakat lainnya. Salah satu kesepakatannya adalah masing-masing rumah di Jawa memiliki jenis kentongan yang berbeda (ukuran dan bentuk) yang akan 
menghasilkan suara berbeda, sehingga dapat menunjukkan identitas masing-masing keluarga tersebut. Namun demikian, tampaknya kearifan lokal ini semakin tergerus dengan kehadiran alat-alat komunikasi modern yang terus bermunculan.

Hasil penelitian di Jawa Tengah dan Jawa Timur menunjukkan bahwa besar-kecilnya kentongan yang dipajang di depan rumah, erat hubungannya dengan status sosial dan kekayaan seseorang. Menurut Sumiyati (2007), status sosial akan menjadi pembeda dalam bentuk dan fungsi kentongan, dimana pada masyarakat biasa umumnya kentongan berukuran kecil dan terbuat dari bambu, sedangkan masyarakat bangsawan, kentongan berukuran lebih besar dan terbuat dari kayu yang dihias. Hal ini mendukung pernyataan Surono (2015) bahwa terkadang masyarakat ingin memberikan tanda untuk menunjukkan kelas sosial mereka yang lebih tinggi dan istimewa. Pada masyarakat Bali, kentongan dominan digunakan sebagai sarana untuk upacara ritual keagamaan. Menurut Yunus et al. (1994), kentongan dipergunakan salah satunya dalam upacara "Panca Yadnya" di Bali, yaitu upacara lima korban suci yang dilakukan atau diterjemahkan dengan hati yang tulus ikhlas dan merupakan salah satu kewajiban bagi umat Hindu.

2. Konservasi keanekaragaman hayati bahan baku

Manusia dalam memenuhi hasrat hidupnya, sering kali melakukan cara-cara yang dapat merusak alam, sehingga mengancam kelangsungan hidup organisme yang ada di dalamnya termasuk tumbuhan. Pembangunan infrastruktur yang sedang giat-giatnya dilakukan, tentunya juga membawa implikasi pada kerusakan lingkungan. Pengelolaan sumber daya alam yang salah dapat berdampak negatif pada ketahanan sumber daya itu sendiri dan berdampak balik pada kehidupan manusia. Sebaiknya kebijakan pembangunan yang dilakukan pemerintah dapat menjaga kelangsungan alam, sehingga dapat dimanfaatkan dalam jangka waktu yang lama dan dapat dinikmati oleh generasi berikutnya (Anonim 2020c).

\section{KESIMPULAN}

Kentongan dikenal sebagai salah satu alat komunikasi tradisional. Kentongan untuk perorangan biasanya berbeda dengan kentongan untuk umum. Terdapat sembilan jenis tumbuhan yang banyak digunakan untuk membuat kentongan, yaitu bambu ori, bambu petung, bambu apus, bambu wulung, kayu nangka, kayu jati, kayu kelapa, kayu mahoni, dan kayu sengon. Masyarakat masih perlu menggunakan kentongan secara lestari untuk mengatur pola hidup secara kebersamaan dalam masyarakat.

\section{UCAPAN TERIMA KASIH}

Penulis mengucapkan banyak terima kasih kepada para mitra bestari yang telah memberi masukan dan saran yang sangat berguna dalam penulisan naskah ini.

\section{DAFTAR PUSTAKA}

Akram M, Aftab F. 2007. In vitro micropropagation and rhizogenesis of teak (Tectona grandis L.). Pakistan Journal of Biochemistry and Molecular Biology 40(3): 125-128.

Anonim 2014. "Coconut botany". Agritech Portal, Tamil Nadu Agricultural University. December 2014. (diakses 28 Agustus 2021).

Anonim. 2020a. Mengenal alat komunikasi tradisional dan modern. https://qwords.com/blog/mengenal-alatkomunikasi-tradisional-dan-modern. (diakses 12 November 2020).

Anonim. 2020b. Kentongan. https://sejarahharirayahindu. blogspot.com/2011/12/ kentongan.html. (diakses 16 Juli 2020).

Anonim : 2020c. Humas Universitas Jambi: Kerusakan alam dan etika pembangunan. https://www.unja.ac.id/ 2020/05/06/kerusakan-alam-dan-etikapembangunan/. (diakses 30 Juli 2021).

Bakker Sj JWM. 1992. Filsafat Kebudayaan Sebuah Pengantar. Kanisius, Yogyakarta.

Dransfield S, Widjaja EA. 1995. Bamboos. Plant Resources of South East Asia (PROSEA) 7. Backhuys Publisher, Leiden.

Hettiaratchi UPK, Ekanayake S, Welihinda J. 2011. Nutritional assessment of jackfruit (Artocarpus heterophyllus) Meal. Ceylon Medical Journal 56: 5458.

Komor P, Devi OS. 2016. Edible bioresources and livelihoods: Artocarpus heterophyllus Lam. Assam State Biodiversity Board, Guwahati, India In: India Biodiversity Portal, Species Page: Artocarpus heterophyllus Lam. https://indiabiodiversity.org/ biodiv/species/show/8042 (Accessed 27 Agustus 2021)

Larasati MD. 2018. Pohon Mahoni: taksonomi, habitat, budidaya, dan manfaat. https://foresteract.com/ pohon-mahoni-taksonomi-habitat-budidaya-danmanfaat (diakses 27 Agustus 2021).

Martin GJ. 1995. Ethnobotany: A Methods Manual. Chapman \& Hall, London. 
Muryanto. 2020. Tak ada pohon ini, Ngawi tidak pernah ada dalam sejarah. https://sambiroto.ngawikab.id/ tag/manfaat-bambu/. (diakses 25 Maret 2021).

Orwa C, Mutua A, Kindt R, Jamnadass R, Anthony S. 2009. ICRAF Agroforestry Tree Database: Albizia chinensis (Osbeck) Merril. http://apps. worldagroforestry.org/treedb/AFTPDFS/Albizia_chi nensis.pdf (diakses 27 Agustus 2021).

Pandit IKN, Kurniawan D. 2008. Anatomi Kayu: Struktur Kayu, Kayu Sebagai Bahan Baku dan Ciri Diagnostik Kayu Perdagangan Indonesia. Institut Pertanian Bogor, Bogor.

Paramudita L. 2014. Perilaku komunikasi masyarakat pada tradisi nyadranan (bersih desa) di Desa Karang Tengah, Kecamatan Bagor, Kabupaten Nganjuk. Skripsi. Fakultas Dakwah Dan Komunikasi, Jurusan Ilmu Komunikasi, Universitas Islam Negeri Sunan Ampel, Surabaya.

Prihatman K. 2000. Nangka (Artocarpus heterophyllus Lamk). Sistem Informasi Manajemen Pembangunan di Pedesaan. BAPPENAS. Jakarta.

Pudjiono. 2014. Produksi Bibit Jati Unggul (Tectona grandis L.f.) Klon dan Budidayanya. Institut Pertanian Bogor Press, Bogor.

Rachman M. 2012. Konservasi nilai dan warisan budaya. Indonesian Journal of Conservation 1: 30-39.

Sadguna IGMI. 2010. Kulkul sebagai simbol budaya masyarakat Bali. https://blog.isi-dps.ac.id/ indrasadguna/?p=22 (diakses 7 April 2021).

Suarna N. 2020. Made Adhi Susila ungkap rahasia buat kulkul, belajar dari tetua. https://baliexpress.jawapos.com/read/2020/04/28 /191415/made-adhi-susila-ungkap-rahasia-buatkulkul-belajar-dari-tetua (diakses 15 Maret 2021).

Sugiyarti C. 2012. Pengaruh posisi memukul kentongan terhadap frekuensi yang dihasilkan. Prodi PSN Konsentrasi Fisika Program Pascasarjana UNY. Yogyakarta. (tidak dipublikasikan).
Suhono B. 2010. Ensiklopedia Biologi Dunia Tumbuhan. PT Lentera Abadi, Jakarta.

Sujarwo W, Arinasa IBK, Peneng IN. 2010. Inventarisasi jenis-jenis bambu yang berpotensi sebagai obat di Kabupaten Karangasem Bali. Buletin Kebun Raya 13(1): 28-34.

Sumiyati F. 2007. Makna lambang dan simbol kentongan dalam masyarakat Indonesia. Jurnal Historia Vitae 21(2): 1-10.

Supriatna N, Kosasih E. 2014. Bambu tali (Gigantochloa apus Kurz). Informasi singkat benih, No. 176, Direktorat Perbenihan Tanaman Hutan. Jakarta.

Surono. 2015. Kentongan: pusat informasi, identitas, dan keharmonisan pada masyarakat Jawa. Jurnal Patrawidya 16(1): 139-156.

Walujo EB. 2004. Pengumpulan data etnobotani. dalam: Rugayah, Widjaja EA, Praptiwi (ed). Pedoman Pengumpulan data Keanekaragaman Tumbuhan. Pusat penelitian Biologi-LIPI, Bogor

Widjaja EA, Karsono. 2005. Keanekaragaman bambu di Pulau Sumba. Biodiversitas 6(2): 95-99.

Widjaja EA. 2001. Identikit Jenis-Jenis Bambu di Jawa. Pusat Penelitian dan Pengembangan Biologi-LIPI, Bogor.

Winarno FG. 2014. Kelapa Pohon Kehidupan. PT Gramedia Pustaka Utama, Jakarta.

Witt A, Luke Q. 2017. Guide to the naturalized and invasive plants of Eastern Africa. In: Witt A, Luke Q. (ed.) $\mathrm{CABI}$ : Invasive species compendium. Wallingford, UK. $\quad$ http://www.cabi.org/cabebooks/ebook/ 20173158959 doi:10.1079/9781786392145.0000 (Accessed 27 Agustus 2021)

Yunus A, Purna IM, Kartikasari T, Rupa IW. 1994. Nilai dan fungsi kentongan pada masyarakat Bali. Proyek Pengkajian dan Pembinaan Nilai-Nilai Budaya Pusat, Direktorat Sejarah dan Nilai Tradisional, Direktorat Jenderal Kebudayaan, Departemen Pendidikan dan Kebudayaan, Jakarta. 